\title{
ICT in the secondary visual arts classroom: A study of teachers' values, attitudes and beliefs
}

\author{
Renata Phelps and Carrie Maddison \\ Southern Cross University
}

\begin{abstract}
For some 20 years the literature has been highlighting a range of benefits to be gained from integrating information and communication technology (ICT) in the teaching of visual arts. However, little research has depicted the 'state of play' regarding visual arts teachers' approaches to technology within the Australian context. This paper reports on a study of 14 visual arts teachers from a rural area of Australia and reveals broad diversity in individual teachers' social, artistic and educational values, attitudes and beliefs about ICT, leading to widely diverse approaches to both their personal and professional use of technology. The paper explores a number of key issues, including: whether teachers perceive dissonance between ICT and visual arts; whether teachers believe it is important to integrate ICT in their teaching; the role ICT is currently playing in classrooms; the issues teachers are experiencing and how teachers approach their own ICT learning. It is argued that effective ICT professional development for teachers must take account of teachers' values, attitudes, beliefs and perceptions not only regarding ICT, but in relation to teachers' own approaches to their personal and professional learning.
\end{abstract}

\section{Introduction}

The integration of information and communication technology (ICT) has become a high priority across Australian schools, just as it has in schools internationally (UNESCO, 2002; Jamieson-Proctor, Burnett, Finger \& Watson, 2006). In New South Wales (NSW), the state in which this research was conducted, new syllabus documents for Stages 4 and 5 (Years 7-10) promote the integration of computer technology across all mandatory teaching areas. The foreshadowed (although currently delayed) implementation of state wide computer skills assessments for all Year 6 and 10 students has also emphasised that schools need to take a strategic and concerted approach to students' ICT skill and knowledge development. The impetus to embrace ICT in visual arts classrooms, however, stems not just from such curriculum directives. The tools and techniques available for visual arts expression have expanded tremendously with the advent of new hardware and software, and ICT provides unique opportunities to extend visual arts teaching and learning. Society now demands new visual literacies for its citizens to function effectively in social and employment contexts. Furthermore, the very nature and interests of students themselves contribute to the changing face of visual arts education.

What little has been written of visual arts teachers' use of technology consistently indicates that, while some teachers have embraced new technologies, many continue to use ICT in a limited manner. Little, if any, research currently addresses the factors that impact on visual arts teachers' willingness to integrate ICT, particularly within the 
Australian context. This paper proposes that the values, attitudes and beliefs of visual arts teachers can have a significant impact on whether they embrace and integrate ICT as part of their teaching practice, and whether they choose to take up professional learning opportunities.

\section{The potential of ICT in secondary visual arts classrooms}

ICT presents unique opportunities for supporting creativity (Brown, 2002) and extending visual arts "beyond clay, crayons and paint" (Stankiewicz, 2004: 88). This potential was recognised as far back as the 1980s when Crowe (1988) commented that ICT could assist with exploring design problems, enhance artistic decision making and provide new opportunities for learning. Since then the literature has continued to highlight the potential for ICT in supporting visual arts teaching: "For visual education these are incredibly exciting times offering new possibilities" (Long, 2001: 262).

Drawing and painting software, digital still and video cameras, electronic portfolios, scanners, colour laser printers, samplers and sound mixers, image manipulation, video editing, 3D animation, Internet and web page construction can all play a role in supporting students' artistic expression (Ashford, 2002; Brown, 2002; Neylon, 1996; Taylor, 1999). Furthermore, as a medium for exploring solutions to design problems (Crowe, 1988; Freedman, 1991; Matthews, 1997), students are able to record and save ideas quickly, manipulate line and colour, modify and incorporate images and employ motion (Hubbard \& Greh, 1991). ICT can allow students who might not possess skills with traditional media to focus more on the message and less on execution of art works, thus enhancing self expression (Long, 2001; Wang, 2002; Wood, 2004). Mistakes can be easily corrected, resulting in decreased anxiety and promotion of experimentation, which lies at the heart of creativity (Freedman, 1991; Grenfell, no date; Hicks, 1993; Wood, 2004). While new technologies do not, of course, replace traditional art processes they do extend the possibilities of art expression, communication and perception (Wang, 2002; Wood, 2004).

With an ever increasing emphasis on still and animated imagery, symbols and iconography in society, analysis, interpretation, extrapolation and evaluation of visual imagery has become just as important as art creation. Students need to be wise consumers, familiar with how the mass media operates (Hicks, 1993) and visual arts education has an important role to play in preparing students as visually literate and critical members of society (Brown, 2002; Schwartz, 1991). Furthermore, as the use of digital media has expanded, new career opportunities have opened up for visual artists. Students with knowledge, skills and proficiency in digital art and design are well situated to obtain employment in commercial visual arts contexts, such as advertising, film, animation and other computer graphic industries (Matthews, 1997; Taylor, 1999). Web 2.0 technologies such as Second Life and Flickr, together with the expanding games industry, represent environments in which digital visual art and design skills provide new opportunities for self expression, as well as enhanced commercial potential.

Technology provides exciting opportunities for enriching and transforming visual arts teaching, providing teachers and students alike with new tools to access, organise and present information and to enrich lessons through multimedia (Bridwell \& McCoy, 1991; Garnons-Williams, 2002; Schwartz, 1991; Wood, 2004). Technology enables the establishment of communities of practice and cooperative learning (Henning, 2000; 
Hicks, 1993; Neylon, 1996), with communication not only between students and teachers, but between students from different schools, countries or cultures, and with practising artists from around the globe. The world wide web also provides a virtual international gallery for students' work (Loveless, 2003). ICT can engage and inspire students, and this has been cited as a factor influencing ready adoptors of ICT (Grenfell, no date; Long, 2001; Wood, 2004).

\section{Literature about visual arts teachers' use of ICT}

Literature since the 1980s has continued to document concern surrounding visual arts teachers' willingness to integrate ICT in their teaching (Duncan, 1997; Matthew, Callaway, Letendre, Kimbell-Lopez \& Stephens, 2002; Rogers, 1995). In almost all instances, teachers' values, attitudes and beliefs, human inertia and resistance to change have been cited as significant contributing factors. These factors have been demonstrated to play a significant role in influencing all teachers' preparedness to embrace ICT (Phelps \& Ellis, 2002; Phelps, Ellis \& Hase, 2001; Phelps, Graham \& Kerr, 2004; Phelps, Graham \& Thornton, 2006; Phelps, Graham, Watts \& O'Brien, 2006). However there are a number of issues specific to visual arts teachers.

For instance, teachers' traditional ideologies concerning the framework of aesthetics, and their beliefs about the incompatibility between technology and art itself, have been identified as barriers to the adoption of ICT (Hicks, 1993; Matthew, Callaway, Letendre, Kimbell-Lopez \& Stephens, 2002; Wood, 2004). Previous studies have indicated that some art teachers view ICT as gimmicky and easily misused, and some fear loss of student creativity (Crowe, 1988) and a focus on replication of art (Rogers, 1995). Interestingly, Taylor (1999) noted that photography, in its early history, faced similar resistance when debate ensued as to whether it should be considered an art form. Additionally, Loveless (2003) documented instances where teachers felt that the school network was set up on a 'business model', which was not helpful in the context of an 'art space'.

Wang (2002) reported continued reluctance on the part of visual arts teachers to embrace new technologies and refers to a study of accomplished art teachers and quality art education (Bamford 2001), within which no mention was made of the inclusion of ICT. While some resistance to integration might be attributable to age, research cited in Delacruz (2004) suggested that, although many art teachers are using more ICT, most use only basic applications (such as word processing) rather than applications designed to support creativity. Wood's (2004) work highlights that, while some teachers believe technology maintains student engagement and provides inspiration, others were concerned that students could be easily distracted by technology.

Resource constraints have been recognised as barriers by a number of writers (Delacruz, 2004; Henning, 2000; Wang, 2002) and these papers also identify poor training opportunities, lack of support and lack of time as significant impacts on visual arts teachers' willingness to integrate ICT. Professional development that does not focus on a specific area of content has been found to be less effective (Wood, 2004).

While we do know that some teachers are integrating ICT in their visual arts teaching with "open minds and a sense of adventure" (Delacruz, 2004), what remains unclear is the extent to which this is occurring across school systems, how practising teachers 
view or learn to apply technology in their professional lives (Phelps, Graham \& Kerr, 2004) and the factors that impact on teachers' willingness to integrate ICT. This dearth of current research is particularly evident in the Australian context.

\section{The context for this research}

The first author of this paper has been involved in teaching courses in ICT for teachers at both undergraduate and postgraduate level over many years. Interaction with preservice visual arts teachers indicated a significant dichotomy in their attitudes and beliefs regarding ICT. While some were extremely confident and had extensive experience in digital media, a significant proportion was amongst the least confident and experienced ICT users in the undergraduate student body. These observations were reinforced through experiences offering teacher professional development programs to secondary teachers. Notably, this course attracted very few volunteer participants from visual arts faculties (Phelps \& Ellis, 2002). Only one teacher from the first four cohorts (approximately 160 teachers) had a visual arts background (notably this teacher was extremely nervous about ICT and did not complete the program).

This study was prompted by these observations and curiosity as to whether there were factors specific to visual arts teachers that impacted on their decision to integrate ICT in their teaching. The research aimed to investigate the factors which influenced visual arts teachers' approach to ICT, and their own professional learning.

\section{Methodology}

A qualitative, interpretive approach was determined to be most appropriate in order to explore in some depth the range of issues related to teachers' values, attitudes and beliefs. The research involved interviews (mostly conducted by phone, but with three conducted face to face) with 14 secondary visual arts teachers employed in Catholic schools in a rural Diocese of NSW. Principals from the nine secondary schools in the Diocese were approached and eight replied and collectively nominated 14 visual arts teachers for the study, all of whom agreed to participate. Interviews of between 20 to 35 minutes duration were held with teachers, to determine:

- their background as a secondary visual arts teacher and visual artist;

- how they used computers personally, professionally and as a visual artist;

- their level of ICT confidence;

- how they perceived the role of ICT in visual arts teaching, including benefits and issues;

- the impact ICT has had on students' learning and creativity;

- how supported they felt in their use of ICT; and

- whether they had participated in any professional development workshops and/or ICT training and what influenced their decisions to be involved in these (or not).

\section{Profiling the participants}

Of the 14 participating teachers, nine were female and five male and their ages ranged from early 20 s to late 40 s with most in their 40 s. Four had been teaching for more than 20 years and nine had been teaching less than ten years (minimum number of years was three). Most had taught at multiple schools in both public and private systems, and began their careers teaching casually. Most taught additional 
subjects other than visual arts. Schools generally had two to three full time visual arts teachers, although one school only had one visual arts teacher on staff.

As outlined in Table 1, interviewees had diverse visual arts backgrounds. Most said they currently had limited or no time for their personal art practice, six citing their teaching work as the main reason for this, followed by family commitments. All of the teachers used word processing and Internet research in their teaching. Ten used specific graphic art software (such as PhotoShop) and nine used digital photography as part of their visual arts teaching. Six made use of data projection in the classroom, three mentioned the use of PowerPoint, and half used scanners and printers. Digital video/film was used by four teachers.

Table 1: A brief profile of participants

\begin{tabular}{|c|c|c|c|c|}
\hline $\begin{array}{l}\text { Pseud- } \\
\text { onym }\end{array}$ & $\begin{array}{l}\text { Years } \\
\text { teach- } \\
\text { ing }\end{array}$ & \begin{tabular}{|} 
Visual \\
arts back- \\
ground
\end{tabular} & $\begin{array}{l}\text { Active } \\
\text { visual } \\
\text { artist? }\end{array}$ & Brief synopsis of current ICT use \\
\hline Beth & 7 & $\begin{array}{l}\text { sculpture } \\
\text { and } \\
\text { ceramics }\end{array}$ & Yes & $\begin{array}{l}\text { Used computers almost daily for personal use and about } \\
\text { every second day as part of teaching. Her confidence was } \\
\text { generally OK. "I wouldn't mind some increased } \\
\text { confidence with things that are new". Did not currently } \\
\text { use any ICT with her own art, although would eventually } \\
\text { like to use PhotoShop. }\end{array}$ \\
\hline Diana & 3 & painting & Yes & $\begin{array}{l}\text { Used ICT every few weeks to document of her own } \\
\text { artwork and present images to galleries. Used home } \\
\text { computer almost every day and was generally confident. } \\
\text { Used ICT every day in teaching, including using a digital } \\
\text { camera to document student art practice and as part of } \\
\text { their body of work. Frequently used a projector and the } \\
\text { Internet with her teaching. }\end{array}$ \\
\hline Helen & $\begin{array}{l}20(14 \\
\text { in VA) }\end{array}$ & * & * & $\begin{array}{l}\text { Tried to keep up with ICT, used it in teaching 2-3 times a } \\
\text { week. Did not feel confident (particularly with seniors). } \\
\text { Owned a computer at home, which her children used } \\
\text { more than her as "there are other things I would prefer to } \\
\text { be doing" }\end{array}$ \\
\hline Isabel & 16 & writer & Yes & $\begin{array}{l}\text { Confident ICT user who enjoyed digital artwork, using } \\
\text { laptop for sketching (PhotoShop). Used ICT everyday in } \\
\text { teaching. }\end{array}$ \\
\hline Jodie & 6 & $\begin{array}{l}\text { fibre } \\
\text { artist }\end{array}$ & No & $\begin{array}{l}\text { Youngest teacher interviewed (in her 20s). Fairly confident } \\
\text { with ICT, used personally about once a week. Classroom } \\
\text { use about once every } 2 \text { weeks with junior classes and } \\
\text { every second day with seniors. }\end{array}$ \\
\hline John & 7 & painting & No & $\begin{array}{l}\text { Eldest interviewee (in his 40s). Used ICT almost every } \\
\text { night for work related tasks. Found ICT frustrating and } \\
\text { time consum-ing. Old computers at school negatively } \\
\text { affected confidence. Rarely used ICT with students and } \\
\text { was concerned about the need to learn PowerPoint for the } \\
\text { following year; "it will be a headache". }\end{array}$ \\
\hline Kate & 17 & * & * & $\begin{array}{l}\text { Reasonably confident with basic ICT, including digital } \\
\text { cameras and PhotoShop, but recognised she had "a long } \\
\text { way to go". Used ICT in the classroom daily or every } \\
\text { second day. }\end{array}$ \\
\hline
\end{tabular}




\begin{tabular}{|c|c|c|c|c|}
\hline Kevin & 22 & $\begin{array}{l}\text { photo- } \\
\text { graphy }\end{array}$ & Yes & $\begin{array}{l}\text { Very confident ICT user. Had 'built' } 5 \text { home computers. } \\
\text { Worked with digital photogra-phy, desktop and web } \\
\text { publishing, graphic design and digital video. Integrated } \\
\text { ICT into every year } 7 \text { and } 8 \text { unit. Used ICT every second } \\
\text { period, including scanning, PhotoShop, page layout, } \\
\text { Internet research and digital video. Desk computer turned } \\
\text { on all day for easy access. }\end{array}$ \\
\hline Liam & 7 & $\begin{array}{l}\text { painting, } \\
\text { drawing, } \\
\text { print } \\
\text { making }\end{array}$ & No & $\begin{array}{l}\text { Very confident with computers used them daily, created } \\
\text { diaries of sketches, scanned and used PhotoShop. Included } \\
\text { digital artwork with all students using PaintPros, digital } \\
\text { photography, digital video and PowerPoint. }\end{array}$ \\
\hline Noah & 8 & $\begin{array}{l}\text { mixed } \\
\text { media }\end{array}$ & Yes & $\begin{array}{l}\text { Confident with ICT. Used computers personally at least } \\
\text { every second day. Although he was "more than confident } \\
\text { to teach the kids the basics", did not use ICT very often in } \\
\text { the classroom, due to limited availability of hardware. }\end{array}$ \\
\hline Sigrid & 22 & fibre arts & No & $\begin{array}{l}\text { Generally very confident, daily personal use of computers. } \\
\text { Only made moderate use of ICT in her teaching; a couple } \\
\text { of lessons a year with younger students but more } \\
\text { frequently with older students. }\end{array}$ \\
\hline Mia & 7 & $\begin{array}{l}\text { print } \\
\text { making }\end{array}$ & No & $\begin{array}{l}\text { Infrequent personal computer use. Confidence was } \\
\text { affected by home computer problems. Did do some digital } \\
\text { photo manipulation using Photoshop. In teaching used ICT } \\
\text { spasmodically, usually once a week. Encouraged student } \\
\text { ICT use, including videoing presentations and having } \\
\text { students email assignments. }\end{array}$ \\
\hline Steve & 5 & $\begin{array}{l}\text { painting } \\
\text { and } \\
\text { drawing }\end{array}$ & Yes & $\begin{array}{l}\text { Generally confident with ICT. Only really used ICT in his } \\
\text { own time for work related tasks. Used with students about } \\
\text { once a month. Described how the students used ICT with } \\
\text { an art exhibition, choosing artists, images and making the } \\
\text { business cards, catalogue and invitations. }\end{array}$ \\
\hline Tarni & 9 & sculpture & No & $\begin{array}{l}\text { Used ICT everyday as part of her teaching (primarily } \\
\text { Internet research) as required by her school. Somewhat } \\
\text { confident, but mainly with junior classes. Felt that she } \\
\text { would need more help if teaching the senior years, } \\
\text { particularly with digitally produced works; "I am not very } \\
\text { skilled in this area... I have been a bit intimidated with } \\
\text { computers". }\end{array}$ \\
\hline
\end{tabular}

* This data was not obtained

Notably, all teachers owned a computer at home, with one interviewee owning five computers. When asked about their personal use of computers, all used word processing, about half used email frequently and the majority used the Internet for research and work related activities. Six teachers used ICT in some way as part of their own art practice, including storing images, digital cameras, Photoshop and graphic design. Two teachers were involved in digital video and editing.

\section{Exploring the issues}

In this section we discuss five key issues, namely:

- do teachers perceive dissonance between ICT and visual arts itself?

- do teachers believe it is important to integrate ICT in their teaching?

- what role is ICT playing in the secondary visual arts classroom?

- what issues are teachers experiencing integrating ICT?

- how do teachers approach their own ICT learning? 


\section{Do teachers perceive dissonance between ICT and visual arts itself?}

While no teachers explicitly expressed beliefs that digital work was at odds with their beliefs and values regarding visual arts itself, there were evident tensions for a number of the teachers interviewed; even those who actively embraced ICT themselves. Six discussed the importance of traditional mediums and the organic nature of art. Diana was the most vocal in expressing her belief that digital work was not, in itself, an art form and that technology made art look easy and did not require any skill. "Some students do a photocopy and think it is an art work". For Diana, part of being an artist is to create an illusion and "ICT can not do that as well as our own imagination". Steve was also passionate about the "organic" nature of art and thought computers were a "bit cold". For him painting was a very personal, absorbing process, not able to be replaced with ICT. Kate expressed her view that computer graphics were really overrated.

Several teachers described ICT as a tool, much like a paintbrush, or a pencil or lino tool. Such comments were often made in the context of digital art forms not replacing traditional techniques. For a smaller number of teachers, technology was perceived as opening up new, exciting and progressive forms of expression. "It can extend the ability to create a body of work, organic to computer to four dimensional works. I love the experience of it" (Mia). Kevin described it as instantaneous and very liberating.

A number of teachers experienced tension regarding aesthetical aspects of engaging with images on screen rather than in books. Isabel, for instance, commented that "turning the pages of a beautiful large art book is a far more sensuous experience than sitting behind a computer screen". Similar sentiments were expressed by John and Helen, who believed that students absorbed information and kept focused best with books.

\section{Do teachers believe it is important to integrate ICT in their teaching?}

Considerable differences existed in teachers' beliefs concerning the importance of ICT in the art classroom. Only six felt that ICT was a necessary, mandatory, fundamental or unavoidable part of contemporary art teaching, while five teachers expressed that ICT was not essential. Mia pointed out that although she believed ICT was an integral part of art, it was possible to achieve well in visual arts courses without ICT.

Four of the teachers saw ICT as important in relation to student career opportunities, for instance as illustrators, graphic designers or architects. A number of teachers commented that integrating ICT positively impacted on perceptions of visual arts as a subject. Jodie, for instance, noted that ICT brought different students into the art room, "not just the painters and drawers" and Liam believed that ICT helped art compete with other subjects; "When we use computers it makes art more attractive, more accountable. When we have subject selections we talk about the role of ICT in art and it makes people sit up and take note".

Seven teachers identified ICT as playing an important role in engaging and motivating students; "ICT is part of the real world; their real world" (Sigrid). "If imagery does not engage them they switch off. You have to be very clever in stimulating the kids and be clever, gimmicky, grandstand a bit to get their attention, or be more charismatic than you had to do" (Isabel). Only one of the teachers talked at length about the role visual arts could play in nurturing critical literacy. Isabel 
thought it was important to support students to be active and critical visual consumers, particularly in relation to advertising; "I talk to my seniors about this all the time. You don't accept an image just because it's presented on a computer screen". For Isabel, an important aspect of her role was to teach students "how to deconstruct, analyse and how to be critical consumers of art".

\section{What role is ICT currently playing in the secondary visual arts classroom?}

The majority of the teachers highlighted the benefits of ICT in accessing, organising and presenting information. Seven teachers, for instance, discussed its role in supporting student research, providing immediacy and the ability to search for obscure artists and art movements. "With ICT we have access to every image and every artist. No books have it all. We can access all galleries, Australian and international" (Liam). These benefits were particular significance for this group of rural teachers as there was a real sense that "the world is at our fingertips" (Kevin). "The world can come to us. In a rural area we are so removed from a lot of culture" (Liam). Jodie explained that technology helps art teachers keep up with what is happening in contemporary art practice, views reinforced by Diana. "We can access more exciting things now, like performance art. Kids can now experience a whole range of art influences, film, technology and art practice. Kids can see what is happening overseas". The ease and efficiency of displaying images, for instance by using PowerPoint and a data projector, was also a strength; "Now images can be larger, on a grander scale; they are more real". Beth commented that she could "reuse it all, it is more interactive, keeps kids occupied. ICT can be quick and allows the classroom to be more dynamic".

While most teachers used ICT for theory, about half indicated that they were using technology with their students to create art works. These teachers indicated that ICT helped students play around with art and see progressive changes. Beth, for example, encouraged her students to use ICT in their body of work, including digital photography and scanning images from pieces they had created.

Interestingly, however, none of the teachers referred to harnessing ICT to transform their pedagogy. For instance, no reference was made to implementing webquests, virtual excursions or other online learning experiences, or to including interpersonal exchanges, with students communicating with other students or artists from the community or from different cultures. No teachers referred to using the web to assist students to exhibit their work.

\section{What issues are visual art teachers experiencing integrating ICT?}

Notably, every teacher interviewed identified resources, support or funding constraints as barriers to ICT use in the art classroom. There was, however, a marked difference between the equipment available across the eight schools. Diana, who was from a newer school, had a data projector in each of the three art rooms, a technical area within the art room with three computers, and an adjoining room that was one of five computer labs in the school. A number of other teachers mentioned having one to two computers in their art rooms, although sometimes they were quite old, and in one case, space restrictions meant that it sat covered by a blanket under the chalk board. Others relied on making use of general school computer labs, and one mentioned having to wait weeks to access the lab and then was only able to do so by negotiating 
with another teacher to have their booked time. Only two teachers indicated that they did not want computers in their art room. For one of these teachers, this was an inconceivable prospect; "I can't imagine schools having computers in the art room. How could they? Kids don't all behave well, some kids are pretty wild. If we have expensive equipment in the art room, we are just asking for it to be wrecked".

A number of teachers were highly vocal about issues of inequity. Hardware availability was associated with broader school values and levels of support and leadership. One interviewee discussed having to make do on a limited art budget. "We could buy pastels for the whole class at $\$ 25$ each or one program. We have to buy books, the list is endless. How far will \$5,000 go on computers and technology? We have been applying for a new scanner, A3 printer and digital camera for the last three years. There is just not that money in the school or priority given to the art room". In this school the two computers in the art room were quite old, unreliable, and one was linked to a printer that another staff member had donated.

While previous studies frequently cite time as a major restricting factor on classroom integration of ICT, in this study it was mentioned by only three teachers. John said he did not have enough time to learn about the application of new technology and that "ICT makes teachers' jobs so much more demanding". Noah and Mia both talked about trying to find time to squeeze more content into an already full program.

Perceptions regarding the influence of ICT on students' approaches to visual arts were diverse. A number of teachers felt that ICT, at times, stifled student creativity or resulted in students not using traditional techniques. Some thought that students with poor ICT skills were not comfortable with ICT based art making and Liam commented that art making via ICT could be "very removed". "Some kids are the hands on kind. ICT can take away their natural ability" (Mia). One teacher commented that students now had too many choices when it came to art making. Contrastingly, Kevin and Diana raised the issue that some students were too reliant on ICT and did not want to draw. Such concerns regarding the 'overuse' of technology were expressed by teachers particularly passionately. A number conveyed reservations, if not fear, that students would no longer develop foundational skills and that ICT took time away from areas such as painting and drawing. "I know that kids are impressed by it... they see it as something new but it's not really...the kids think it's an end product not a tool" (Kate). Noah felt it was important to get the kids to think creatively first before they used ICT.

Some issues were raised regarding students' over reliance on the web for information, about Internet information being at times invalid and students losing the ability to research with books. Although the issue of plagiarism (copy and pasting and changing a few words) was raised by a small number of interviewees, the more specific issue of "scanning and manipulating images" was also discussed. These concerns were interesting given that appropriation has such a firm foundation in art history. Sigrid acknowledged that many contemporary art works were now 'borrowed', however her concern was that "if kids rip off and don't understand what they are doing it can be a problem, but not if they initiate an idea". For Noah, concerns related to not being able to see the development of students' digital art work. "I need to see their workbooks, I need to see the stages of the work... as I would a sketch to painting". This comment perhaps reflects a lack of awareness or understanding of versioning strategies or assessment techniques such as digital portfolios. 


\section{How do teachers approach their own ICT learning?}

The professional development and learning approaches being employed by visual arts teachers in relation to ICT, and their values and attitudes to this learning, were a particular interest in this study. Interviewees discussed the need to continually keep up with ICT skills and knowledge, and for many this was highly confronting. One teacher described ICT as "an anchor around my neck". Tarni emphasised that a lot of teachers fear being left behind professionally, and Isabel reflected some teachers panic about ICT learning. "It's ignorance and that breeds fear and mistrust. People think it's a huge thing they have to learn and it is scary. It is no different to any other skill you or the kids learn in the classroom". This anxiety was clearly evident in the comments of John; "I want someone to come here and tell me as I don't know what to do. We have a new photocopier here but it is impossible to use! No one here to show me the basics, so it is hit and miss. It needs to be in easy steps, and we need easier programs for teachers to use".

Nine of the 14 teachers had undertaken some form of ICT professional development, with most of such activities having been carried out at school and covering skills with reporting software, word processors and publishing software, web page design, PowerPoint, spreadsheets and Moodle. Two teachers had undertaken an Adult Community Education course and one teacher had completed a course through Technical and Further Education (TAFE). Only four teachers had undertaken professional development specific to visual arts (for instance on graphic art programs or digital imaging). Kevin was himself trying to organise and run a professional development workshop for other teachers in the Diocese.

A range of factors were cited as influencing teachers' decision to be involved in ICT professional development. Notably, two teachers stated that they were not at all interested in ICT and thus not willing to be involved. In contrast, some indicated that they were already confident with ICT and thought that the type of professional development offered was not suitable for them. Four said most of the courses they would like to attend were only available in capital cities. Three of the female teachers said they found attending professional development out of school hours difficult because of family commitments. Having to meet the costs personally was cited as a barrier and one interviewee mentioned the timing of initiatives as problematic (e.g. first day of term). Several teachers referred to themselves as self taught, learning by playing around and talking to their colleagues, family or friends; "Basically the way I learnt was to get on and do it. I feel confident that either I will figure out what to do or ask someone" (Isabel). "When exploring something new I need a fair bit of time or else I tend to put it off until I feel comfortable" (Sigrid). Jodie made a suggestions that team teaching would be a very affective learning approach.

While five teachers believed they did not receive enough ICT support, the majority were happy with the assistance available; "There is heaps and heaps of help from people who are self motivated or self taught and are more than willing to teach other teachers" (Helen). For John it was an issue of "we discuss it or we sink". Some teachers saw principals as supportive, although this was countered by others.

Many interviewees commented that their students were at times more skilled in ICT than them. Notably it was the more confident computer users who indicated that they were happy to learn alongside their students. Liam, for instance, stated that "if I do not know I put it on the line and tell the kids. I tell them that teachers don't know 
everything. We do it together and that really builds kids' confidence. It is two way learning". Jodie similarly stated that "I am not stressed with it all. I am learning with the kids. I let them know if I don't know something". Steve also reinforced the value of these strategies, stating that "I have a good relationship with the kids. I am here to learn as well, so I don't mind asking them".

\section{Discussion}

Interviews with these 14 Australian rural teachers indicated that there is still considerable diversity in the extent to which visual arts teachers are integrating ICT in their teaching and that for some teachers, perceived dissonance between ICT and the creative and tactile process of visual art is indeed a contributing factor.

Length of time teaching did not impact negatively on ICT integration with some of the most experienced teachers being prolific in their use of ICT. Relatively recently graduated teachers (under ten years) were not necessarily integrating ICT more frequently or creatively than those with more experience.

The majority of teachers could articulate advantages and potential for ICT integration, particularly related to student engagement and motivation. However, a minority felt obligated to do so by wider educational pressures, imperatives or developments, and only a small number spoke of broader social needs for digital visual art literacy. Less than half of the teachers interviewed thought ICT was a fundamental part of the visual arts curriculum, despite recent syllabus changes. Many of the teachers interviewed did perceive tensions between ICT and visual arts practice and expressed concerns that using ICT would somehow undermine and replace, rather than supplement, traditional approaches.

Significant diversity was discovered between schools in relation to access to hardware and software, and this certainly did influence teachers' willingness to integrate ICT in their teaching. School finances, culture and leadership invariably impacted on this resourcing, however where teachers were not interested in integrating ICT, it may well be that little pressure was being exerted to pursue technology based resources.

A key finding relates to teacher learning. As has been supported in other research (Tearle, 2003; Phelps, Graham \& Kerr, 2004; Phelps, Graham, Watts \& O’Brien, 2006) those who are proficient and capable ICT using teachers learn predominantly through self directed play and exploration, while being supported by colleagues, friends and family, rather than remaining reliant on formal training or professional development. While workshop based approaches can provide a useful means of introducing new ideas, ultimately the most effective learning is occurring for teachers by 'getting in and having a go'. Building networks and encouraging dialogue between teachers specifically in relation to ICT should be seen as important, not just in passing on skills and knowledge but also as a means to addressing discipline specific concerns and influencing values and beliefs. As has been highlighted in other studies (Phelps, Graham \& Thornton, 2006; Phelps, Graham, Watts \& O'Brien, 2006), explicit collegial discussion concerning learning strategies can promote risk taking and encourage more ICT reluctant teachers to learn with and from their students.

In rural areas of Australia, where considerable distances stand between secondary schools, and where teachers may find themselves as the only visual arts teacher within a school (or one of only two), the importance of facilitating dialogue and idea sharing 
between schools is difficult but critical. The study indicated instances where teachers remained quite unaware of the level to which other schools were integrating ICT, and continued to see such integration as inconceivable. The diversity across the schools also reinforced that some level of benchmarking may prove essential, to attempt to diminish inequities in outcomes for students. Ultimately, however, teachers need to hold values, attitudes and beliefs that will lead them to support integration initiatives. Data obtained in this study would reinforce a level of optimism in this respect.

\section{Conclusion}

This study indicates that the adoption and integration of ICT by visual arts teachers is as similarly diverse as that by teachers more broadly. While some teachers have led the way with innovative and exciting applications of technology, others continue to avoid it all together and this is exacerbated and perpetuated by beliefs about the nature of visual arts and the relationship between technology and creativity. This study reinforces the findings of other studies that suggest professional development is not simply about 'attending courses' or 'receiving training', but that it is much more complex and proactive, and requires a clear emphasis on addressing not just 'how' to do it, but on 'why' it should be done (Higgins \& Mosley, 2001). Certainly, understanding teachers' beliefs and values is a vital ingredient in effective support (Taylor, 1999) and studies such as this are essential in enabling school systems to support teachers in ways which take account of teachers' values, attitudes, beliefs, motivations, and discipline specific concerns.

\section{Acknowledgements}

The authors would like to acknowledge the formative role of Chris Sanders in this research and the contribution of the 14 teachers who kindly offered their time and support to the study. Special thanks also to the Lismore Diocese Catholic Education Office for their support of this research and their commitment to supporting teachers' ICT professional learning.

\section{References}

Ashford, J. (2002). The arts and crafts computer: Using your computer as an artist's tool. Pearson.

Bridwell, G. M. \& McCoy, M. (1991). Dissemination of computer graphics in Indiana: Teachers teaching teachers. Art Education, 54-60.

Brown, I. (2002). New radicalism for art education: Embracing change. Australian Art Education, $25(1), 62-64$.

Crowe, B. (1988). Computers in secondary school art curriculum: Painting a picture of effective teaching. Paper presented at the Annual meeting of the Mid-South Educational Research Association, Lexington.

Delacruz, E. (2004). Teachers' working conditions and the unmet promise of technology. Studies in Art Education, 46(1), 6-20.

Duncan, P. (1997). Art education and information technology. Journal of the Australian Institute of Art Education, 20(3), 47-50.

Freedman, K. (1991). Possibilities of interactive computer graphics for art instruction: A summary of research. Art Education, 41-47. 
Garnons-Williams, V. (2002). Lines of inquiry: Negotiating instructional resources in the age of information. Paper presented at the Australian Association for Research in Education (AARE), Brisbane, Qld. http:/ / www.aare.edu.au/02pap/gar02330.htm

Grenfell, J. (no date). Art education: Teaching the visual arts, technology and the visual arts. [viewed 2 Dec 2004; not found 22 Dec 2007]. http: / / www.deakin.edu.au/education/visarts/technology\&thearts.pdf

Henning, G. (2000). Introducing digital technologies into the year 9/10 visual arts program: Cooperative learning in action. Australian Art Education, 23(2), 37-41.

Hicks, J. (1993). Technology and aesthetic education: A critical synthesis. Art Education, November, 42-47.

Higgins, S. \& Mosley, D. (2001). Teachers' thinking about information and communications technology and learning: Beliefs and outcomes. Teacher Development, 5(2), 191-210.

Hubbard, G. \& Greh, D. (1991). Integrating computing into art education: A progress report. Art Education, 18-24.

Jamieson-Proctor, R., Burnett, P., Finger, G., \& Watson, G. (2006). ICT integration and teachers' confidence in using ICT for teaching and learning in Queensland stage schools. Australasian Journal of Educational Technology, 22(4), 511-530. http:/ / www.ascilite.org.au/ajet/ajet22/jamieson-proctor.html

Long, S. (2001). Multimedia in the art curriculum: Crossing boundaries. Journal of Art and Design Education, 20(3), 255-263.

Loveless, A. (2003). Making a difference? An evaluation of professional knowledge and pedagogy in art and ICT. Journal of Art and Design Education, 22(2), 145-154.

Matthew, K., Callaway, R., Letendre, C., Kimbell-Lopez, K. \& Stephens, E. (2002). Adoption of information communication technology by teacher educators: One-on-one coaching. Journal of Information Technology for Teacher Education, 11(1), 45-61.

Matthews, J. (1997). Computers and art education. Reston, VA: The National Art Education Association.

Neylon, J. (1996). I couldn't do my homework, the cat ate my mouse. Artlink, 16(2 \& 3), 54-56.

Phelps, R. \& Ellis, A. (2002). A metacognitive approach to computer education for teachers: Combining theory and practice for computer capability. Paper presented at the Linking Learners: Australian Computers in Education Conference (ACEC2002), Hobart, Tasmania: http:/ / www.pa.ash.org.au/acec2002/ confpapers / paperdetails.asp?orgid=1\&suborgid=1\&s sid $=111 \&$ pid $=617 \&$ ppid $=0$ \&uid $=\&$ docid $=117$

Phelps, R., Ellis, A. \& Hase, S. (2001). The role of metacognitive and reflective learning processes in developing capable computer users. In Meeting at the Crossroads: Proceedings ASCILITE 2001. Melbourne: University of Melbourne. http:/ / www.ascilite.org.au/conferences/melbourne01/pdf/papers/phelpsr.pdf

Phelps, R., Graham, A. \& Kerr, B. (2004). Teachers and ICT: Exploring a metacognitive approach to professional development. Australasian Journal of Educational Technology, 20(1), 49-68. http:/ / www.ascilite.org.au/ajet/ajet20/phelps.html

Phelps, R., Graham, A. \& Thornton, P. (2006). Technology Together: Getting whole schools involved with ICT through a metacognitive approach. The Australian Educational Leader, $28(1), 22-24$ 
Phelps, R., Graham, A., Watts, L. \& O'Brien, A. (2006). Technology Together: Supporting wholeschools to become capable learning communities. Australian Computers in Education Conference (ACEC) 2006, Cairns, 2-4 October. [verified 22 Dec 2007] http: / / acec2008.info/ confpapers / paperdetails.asp?pid $=7213 \&$ docid $=692$

Rogers, P. (1995). Towards a language of computer art: When paint isn't paint. Art Education, September, 17-33.

Schwartz, B. (1991). The power and potential of laser videodisc technology for art education in the 90's. Art Education, May, 9-17.

Stankiewicz, M. (2004). Notions of technology and visual literacy. Studies in Art Education, 46(1), 88-92.

Taylor, S. (1999). A computer convert's story. EQ Australia. [verified 22 Dec 2007] http: / / www1.curriculum.edu.au/eq/archive/prior2002/eq_99/taylor.htm

Tearle, P. (2003). Enabling teachers to use information and communication technology for teaching and learning through professional development: Influential factors. Teacher Development, 7(3), 457-471.

UNESCO (2002). Information and Communication Technologies and Teacher Education. Paris: UNESCO. http:/ / www.eldis.org/ static/DOC10100.htm

Wang, L. (2002). How teachers use computers in instructional practice: Four examples in American schools. Journal of Art and Design Education, 21(2), 154-163.

Wood, J. (2004). Open minds and a sense of adventure: How teachers of art \& design approach technology. The International Journal of Art E Design Education, 23(2), 179-191.

Renata Phelps and Carrie Maddison

School of Education

Southern Cross University

PO Box 157, Lismore NSW 2480, Australia

Email: rphelps@scu.edu.au, carrie.maddison@scu.edu.au 